\title{
Spatiotemporal associations between Pacific herring spawn and surf scoter spring migration: evaluating a 'silver wave' hypothesis
}

\author{
Erika K. Lok ${ }^{1,6, *}$, Daniel Esler ${ }^{1}$, John Y. Takekawa ${ }^{2}$, Susan W. De La Cruz ${ }^{2}$, \\ W. Sean Boyd ${ }^{3}$, David R. Nysewander ${ }^{4}$, Joseph R. Evenson ${ }^{4}$, David H. Ward ${ }^{5}$ \\ ${ }^{1}$ Centre for Wildlife Ecology, Simon Fraser University, 5421 Robertson Road, Delta, British Columbia V4K 3N2, Canada \\ ${ }^{2}$ U.S. Geological Survey, Western Ecological Research Center, San Francisco Bay Estuary Field Station, 505 Azuar Drive, \\ Vallejo, California 94592, USA \\ ${ }^{3}$ Environment Canada, Pacific and Yukon Region, 5421 Robertson Road, Delta, British Columbia V4K 3N2, Canada \\ ${ }^{4}$ Washington Department of Fish and Wildlife, 600 Capitol Way North, Olympia, Washington 98501, USA \\ ${ }^{5}$ U.S. Geological Survey, Alaska Science Center, 4210 University Dr., Anchorage, Alaska 99508, USA \\ ${ }^{6}$ Present address: Environment Canada, Pacific and Yukon Region, 5421 Robertson Road, Delta, British Columbia V4K 3N2, \\ Canada
}

\begin{abstract}
Surf scoters Melanitta perspicillata are sea ducks that aggregate at spawning events of Pacific herring Clupea pallasi and forage on the eggs, which are deposited in abundance during spring at discrete sites. We evaluated whether migrating scoters followed a 'silver wave' of resource availability, analogous to the 'green wave' of high-quality foraging conditions that herbivorous waterfowl follow during spring migration. We confirmed that herring spawning activity began later in the year at higher latitudes, creating a northward-progressing wave of short-term localized food availability. Using satellite telemetry and aerial surveys, we documented the chronology of scoter spring migration and the use of stopover locations in relation to herring spawn timing and locations. We found that the migration chronology paralleled the northward progression of herring spawning events. Although there was considerable variability in the timing of both scoter migration and the initiation of herring spawning, the processes were related beyond a coincidental northward progression. During migration, $60 \%$ of the tracked scoters visited at least 1 spawn site, and those that used spawn sites were located on spawn sites for approximately one-third of their migration locations. Surf scoters showed close spatiotemporal associations with herring spawning events, confirming that the presence of herring spawn was a factor determining habitat use for many individuals. Surf scoters showed close spatiotemporal associations with herring spawning events, confirming that the presence of herring spawn was a factor determining habitat use for many individuals, a conclusion that is consistent with previous studies which used physiologically based metrics to evaluate the importance of herring spawn.
\end{abstract}

KEY WORDS: Habitat use $\cdot$ Herring spawn $\cdot$ Melanitta perspicillata $\cdot$ Migration $\cdot$ Satellite telemetry $\cdot$ Surf scoter

Resale or republication not permitted without written consent of the publisher

\section{INTRODUCTION}

Migrating animals face habitat and food resources that vary considerably over both time and space at local, regional, and continental scales. The timing of migration and the choice of habitats are shaped by spatiotemporal variation in resource availability, and migrating animals are known to adopt optimal migration strategies in light of this variation (Ottich \& Dierschke 2003, van der Graaf et al. 2006). Many 
migratory birds acquire energy and nutrient reserves at spring stopover sites, and the availability and quality of resources at these sites can have implications for success during subsequent stages of the annual cycle (Ryder 1970, Ankney \& MacInnes 1978, Alisauskas \& Ankney 1992, Warnock \& Bishop 1998, Smith \& Moore 2003, Morrison \& Hobson 2004). Therefore, the timing of migration and the choice of stopover habitat can have population-level demographic consequences.

Migrating herbivorous birds are speculated to strategically time their migration to take advantage of the emergent spring growth of forage plants at stopover and staging sites (van der Graaf et al. 2006). This 'green wave' hypothesis posits that birds migrating from wintering areas to Arctic breeding areas follow the northward-progressing wave of emergent spring vegetation (Drent et al. 1978, Owen 1980). Stopover site use by some migrating waterfowl appears to be closely linked to peaks in forage biomass and quality during spring (van der Graaf et al. 2006).

The availability of other food resources for migrating animals may also vary temporally along a latitudinal gradient. In coastal ecosystems, many birds and mammals exhibit aggregative responses to ephemeral seasonal resource pulses, such as Pacific herring Clupea pallasi spawning events (Haegele 1993, Bishop \& Green 2001, Sullivan et al. 2002, Womble et al. 2005). Across their range throughout the north Pacific Ocean, Pacific herring spawn from late winter to early summer, and in general, spawning is initiated later at higher latitudes. This general latitudinal progression of spawning events is probably the result of the initiation of spawning by sea temperatures $>6^{\circ} \mathrm{C}$ (Haegele $\&$ Schweigert 1985). Herring spawning events are short-lived, with spawning activity occurring within a span of 3 to $6 \mathrm{wk}$ in any given area, and the eggs hatch 1.5 to $3 \mathrm{wk}$ after deposition (Haegele \& Schweigert 1985, Hay 1985). Herring spawning events are typically limited to relatively sheltered inlets, bays, and estuaries (Haegele \& Schweigert 1985). In the northeastern Pacific, despite the abundance of relatively protected shoreline along the coast of British Columbia (BC), Canada, and Southeast Alaska (SEAK), USA, spawning events are also highly localized, occurring on $<2 \%$ of the entire BC coastline in a given year (Hay \& McCarter 2007). It is likely that the proportion of shoreline used in SEAK is similar.

Spawning events provide food resources to a number of avian predators (Bishop \& Green 2001, Sullivan et al. 2002, Rodway et al. 2003). Herring spawning activity occurs at generally the same time that many birds are migrating along the coast to northern breeding areas. Therefore, we propose a 'silver wave' hypothesis, analogous to the green wave hypothesis for herbivorous birds, which posits that migration timing and habitat choice by migrating birds correspond to herring spawning locations and a northward-progressing spawn chronology. Use of these ephemeral and energy-rich herring spawn resources has been documented for both birds and mammals on local and regional scales (Rodway et al. 2003, Womble et al. 2005, Žydelis \& Esler 2005) but has not been considered on a migratory flyway scale.

Until recently, little was known about the migration patterns of many sea ducks, including the surf scoter Melanitta perspicillata. Recent work by De La Cruz et al. (2009) provides a thorough synthesis of Pacific surf scoter migration patterns, routes, and chronology. In general, most tracked scoters followed 2 major routes to the breeding area: either a southern inland route involving staging in southern BC or Washington State, followed by direct migration inland or a northern coastal route characterized by smaller movements along the Pacific coast of BC and SEAK, followed by inland migration from SEAK. During most of the year, scoters feed on bivalves and a variety of soft-bodied prey when in marine waters (Vermeer 1981, Anderson et al. 2008). Along the Pacific coast, surf scoters are known to congregate and forage at herring spawning events during late winter and early spring (Vermeer 1981, Vermeer et al. 1997, Sullivan et al. 2002, Lok et al. 2008). Proximity to herring spawn has been identified as a strong predictor of stopover habitat use (Lok et al. 2011). However, unlike other food resources, the silver wave of herring spawn is restricted to only a few weeks and along a very small proportion of the available coastline (Hay \& McCarter 2007). This pattern has been speculated upon (Vermeer 1981, Savard et al. 1998), but no data have been available to test the silver wave hypothesis.

We examined the timing and stopover locations of spring-migrating surf scoters in relation to Pacific herring spawn to test whether observed migration patterns are consistent with the silver wave hypothesis. First, we investigated a basic assumption of the silver wave hypothesis: whether the timing of Pacific herring spawning activity progressed northward along the BC and SEAK coasts through the spring months within the studied years. Second, we documented migration patterns of surf scoters using satellite telemetry and contrasted these patterns with the availability of herring spawn. Finally, we used survey data to assess whether surf scoters were specifically associated with herring spawning events at 3 areas in SEAK. 


\section{MATERIALS AND METHODS}

\section{Study area}

The wintering range of surf scoters along the Pacific coast extends from Alaska to Baja California, Mexico (Savard et al. 1998). All data were collected from spring-migrating surf scoters originating from several areas throughout this wintering range: San Quintin Bay (SQ), Baja California, Mexico (30.4 N, $\left.116.0^{\circ} \mathrm{W}\right)$; San Francisco Bay (SF), California, USA $\left(37.8^{\circ} \mathrm{N}, 122.4^{\circ} \mathrm{W}\right)$; Puget Sound (PS), Washington, USA $\left(47.5^{\circ} \mathrm{N}, 122.4^{\circ} \mathrm{W}\right)$; and the Strait of Georgia (SG), British Columbia, Canada $\left(49.3^{\circ} \mathrm{N}, 122.4^{\circ} \mathrm{W}\right)$. In the spring, surf scoters migrate along the Pacific coast from these wintering areas to inland breeding areas throughout the boreal forest of western Canada and Alaska (Savard et al. 1998, De La Cruz et al. 2009, Takekawa et al. 2011). Habitats along the coasts of British Columbia and southeast Alaska are variable, from exposed west aspect shores of the Pacific Ocean to very sheltered fjords and tidewater

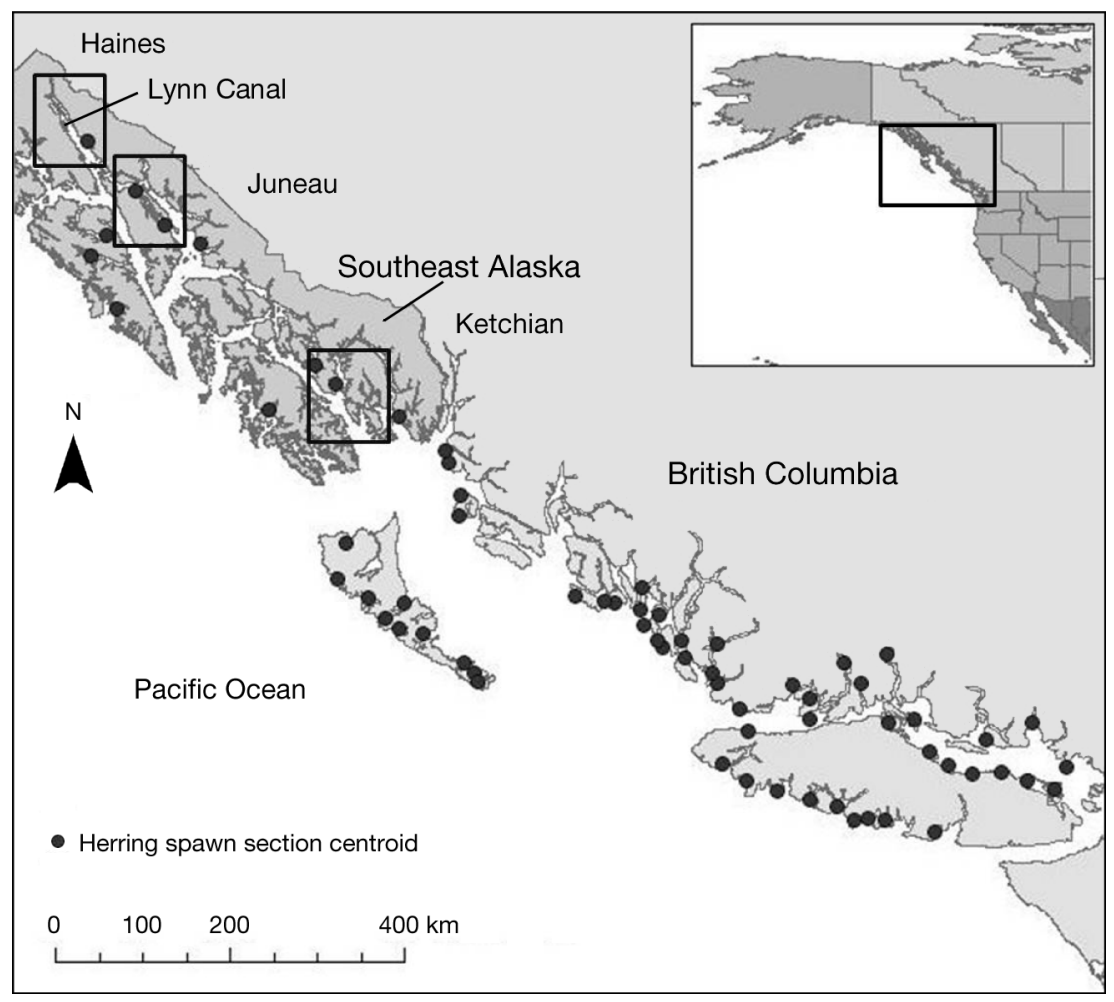

Fig. 1. Pacific herring Clupea pallasi management section centroids along the coasts of British Columbia and southeast Alaska. Only sections that had documented spawning activity from 2003 to 2006 are shown. Survey regions are highlighted by boxes; note that not all coastline within highlighted regions was surveyed glaciers along protected inside passages. The coast of BC and southern part of SEAK have extensive networks of islands and protected bays and channels, while the northern part of SEAK has numerous long fjords and several large soft-bottomed river deltas. Although $\sim 20 \%$ of the BC coast has been used for herring spawning at some time (DFO 2008), most spawning is concentrated and localized to roughly $2 \%$ of the coast in a given year (Hay \& McCarter 2007).

\section{Herring spawn data}

We created a database documenting the distribution and timing of major herring spawning events along the BC and SEAK coast from 2003 to 2006 using existing data from the Department of Fisheries and Oceans (DFO) and the Alaska Department of Fish and Game (ADFG). The DFO Pacific Herring Geographic Bulletin dataset is available online (DFO 2008) and reports the timing and magnitude of herring spawning in 101 management sections which cover the entire $\mathrm{BC}$ coast each spawning season. The dataset also includes the centroid position for each section, which is determined by calculating the mean latitude and longitude coordinates of all the recorded spawning events within the section (Fig. 1). The dataset reports the earliest date of spawning (min. date) and latest date of spawning (max. date) within a year for each section. The mean spawning date was considered the most representative date of the majority of spawning herring in a section (B. McCarter pers. comm.). We compiled the location and timing of herring spawning within similar management sections of SEAK from the ADFG and unpublished sources (J. Womble unpubl. data). For analyses of platform-transmitter-terminal (PTT) scoter locations, we considered spawning distribution and timing for BC and SEAK combined. For aerial survey analyses, we compiled geographic information system (GIS) coverage of herring spawning event distribution within SEAK during the study years. 


\section{Captures and fitting of transmitters}

We captured surf scoters on wintering grounds between November and March in 2002 to 2006 using a floating mistnet (Kaiser et al. 1995, Lewis et al. 2005), or a net shot from a netgun (Coda netgun, Coda Enterprises). The birds were implanted with PTT satellite-transmitters following standard procedures (Mulcahy \& Esler 1999). The implantation method has been shown to perform well for scoters (Iverson et al. 2006). Birds were released after a recovery period of at least $1 \mathrm{~h}$. Individuals that did not leave winter areas, died, or experienced radio failure during migration were not included in analyses. Migration location data were obtained from 75 surf scoters fitted with PTT transmitters in 2003 to 2006 from the 4 wintering areas, SQ, SF, PS, and SG. Of these, 51 individuals (68\%) migrated along the coasts of $\mathrm{BC}$ and $\mathrm{SEAK}$; the remainder of the tracked birds migrated using other inland migratory routes. Detailed information on the migration patterns, routes, and chronology of these surf scoters was reported by De La Cruz et al. (2009).

\section{Location data}

The PTT transmitters were programmed with duty cycles to transmit location data for 6 to $8 \mathrm{~h}$ and turn off for 48 to $96 \mathrm{~h}$. Transmitter signals were received by U.S. National Oceanic and Atmospheric Administration polar-orbiting weather satellites, and CLS America (Largo, Maryland) estimated the transmitter location on the basis of Doppler shifts in transmitter frequencies. Location accuracy classes were determined based on satellite-to-PTT geometry, the number of transmissions received from the PTT, and the stability of the PTT transmission frequency during a satellite pass. For location classes (LC) 3, 2, 1, and 0, in which at least 4 messages are received, CLS America rated accuracy as $<150,<350,<1000$, and $>1000 \mathrm{~m}$, respectively. Accuracy was not provided for LC A (3 messages received), LC B (2 messages) and LC Z (latitude and longitude often provided if $>1$ message received, but the information was considered invalid). Data for scoters from each wintering site were compiled at the USGS Western Ecological Research Center and filtered using an automated systematic plausibility test of direction, distance, and rate of movement between locations (Douglas 2006). The filtering program was set to ensure that the LC 1 to 3 locations were always retained (De La Cruz et al. 2009).
To select only coastal spring migration locations along the coastline of BC and SEAK, this dataset was then manually filtered. Surf scoters maintain small home ranges in the winter months (Kirk et al. 2008); a bird was classified as migrating when it had left wintering grounds and at least 2 consecutive locations were located at increasing latitudes. Location data usually included $>1$ useable location per bird in a transmission day, and a 'selected location' for each transmission day was determined according to the criteria described by Miller et al. (2005). These criteria favor locations with LC 3, 2, and 1 but recognize that accurate locations are obtained for a large proportion of locations within all location classes. Although less conservative than filtering out locations with lower location quality classes or filtering completely randomly, this method allowed us to maximize the number of selected locations during the short migration period, and $91 \%$ of the selected locations were of LC 1 or higher.

\section{Aerial surveys}

We conducted aerial surveys to document the distribution and abundance of surf scoters both before and during the herring spawning and scoter migration period in 2006. Surveys were conducted along the shoreline in 3 regions of SEAK: Ketchikan, Juneau, and Haines (Fig. 1). All 3 regions were surveyed at least once prior to herring spawning initiation (1 to 2 April 2006). During the spawning and migration period, the Ketchikan region was surveyed twice (20 April 2006 and 24 April 2006), the Juneau region was surveyed once (8 May 2006), and the Haines region was surveyed twice (9 May 2006 and 15 May 2006). Surveys were conducted between 09:00 $\mathrm{h}$ and 16:00 $\mathrm{h}$ in a Cessna 185 or Heliocourier with an experienced survey pilot and 1 observer on the passenger side. Surveys followed the shoreline at altitudes of 150 to $200 \mathrm{~m}$ and flight speeds of $<200 \mathrm{~km} \mathrm{~h}^{-1}$. Survey routes varied in shoreline length between regions (Ketchikan: $540 \mathrm{~km}$, Juneau: $463 \mathrm{~km}$, and Haines: $394 \mathrm{~km}$ ), and the survey duration varied accordingly. Surf scoters typically forage close to the shoreline due to water depth and food availability (either bivalves or herring spawn), and previous observations indicated that scoters were typically within $500 \mathrm{~m}$ of the shore in the fjord habitat typical of SEAK. We used digital marine charts (NOAA 1:250 000) to record locations of all observed surf scoters within $500 \mathrm{~m}$ of the shoreline; groups were recorded as a single location with an estimate 
of the group size. Groups of $<100$ were counted individually; larger groups were estimated by counting smaller groups of 10,100, or 1000, depending on the size of the group. Surf scoter flocks exhibit synchronous diving behavior, which made the use of photographs for documenting flock size challenging. However, some photographs were used to confirm the flock size estimates.

\section{Data analyses}

Spawning progression and migration patterns

We used least-squares general linear models to evaluate the variation in latitude of herring spawning activity along the $\mathrm{BC}$ and SEAK coasts in relation to the year and the day of the year (SAS Institute 2003). We included the day-of-year variable as an indicator of seasonal progression, where 1 January $=1$, while the year variable and day-of-year by year interactions were included to account for potential interannual variation in this relationship. We used an information theoretical approach to model selection (Burnham \& Anderson 2002) and calculated Akaike's information criterion adjusted for small sample sizes $\left(\mathrm{AIC}_{\mathrm{c}}\right)$ for each model within the candidate set. The candidate model set consisted of the following models: (1) Day-of-year, (2) Year, (3) Day-of-year + Year, (4) Day-of-year + (Day-of-year $\times$ Year), (5) Day-ofyear + Year + (Day-of-year $\times$ Year), and (6) a null model. We compared the $\mathrm{AIC}_{\mathrm{c}}$ value of each model to that of the best-fitting model $\left(\Delta \mathrm{AIC}_{\mathrm{c}}\right)$ to assess the relative support for each candidate model. We calculated $\mathrm{AIC}_{\mathrm{c}}$ weights $\left(w_{i}\right)$ to compare the relative support for each model within the candidate model set and calculated $\mathrm{R}^{2}$ values to indicate the overall model fit. Finally, we calculated model-averaged parameter estimates and unconditional standard errors based on Akaike weights for all of the candidate models (Burnham \& Anderson 2002).

For the silver wave hypothesis to be supported, we would expect a general correspondence between herring spawn availability and scoter locations, assuming that the basic premise that herring spawning progresses northward over time is correct. We compared the temporal and spatial patterns of herring spawn availability with those of PTT-fitted scoter locations. Estimates of the average spawning latitude for each date were calculated from model-averaged parameter estimates based on Akaike weights (Burnham \& Anderson 2002) across the models in the candidate set describing the relationship of herring spawning date by latitude (see above). We then regressed the latitude of observed scoter locations against estimates of the average latitude of herring spawn for the date of each bird location sample; based on the silver wave hypothesis, we would expect a positive relationship, with a slope of $\sim 1$, indicating that the scoters are following the progression of herring spawn availability exactly.

We recognize that a positive relationship between scoter locations and herring spawning latitude could simply be a spurious result occurring because these phenomena are both northward-progressing during the spring but might not be directly related. To address this issue, we performed separate analyses to calculate residuals from regressions with day-ofyear as the response variable and herring spawning latitude and scoter location latitude as explanatory variables; the residuals were calculated from yearspecific regressions to account for any annual variation. We then regressed the residuals from these analyses against one another, with scoter locations matched with the closest spawning event for that year. A positive relationship between the residuals would indicate that herring spawning and scoter occurrences are spatially and temporally correlated beyond their similarity as northward-progressing phenomena.

\section{Spawning event use metrics}

The silver wave hypothesis predicts a general latitudinal correspondence between locations of migrating scoters and herring. However, we recognize that a single mean date for each spawning event does not fully represent herring spawn availability over time and space, so we plotted scoter locations against herring spawn availability to illustrate the spatiotemporal overlap. Based on the silver wave hypothesis, there should be close correspondence between scoter locations and sites with available herring spawn. Unlike the green wave for herbivorous birds, in which resource availability occurs in a broad swath related to latitude, herring spawning occurs at small, spatially discrete sites, and the silver wave hypothesis requires confirmation that these specific sites are used by migrating birds.

Satellite telemetry location data were imported into ArcGIS 9.1 (Environmental Systems Research Institute 2005) to create a map of surf scoter spring migration and herring spawning locations. Because spawning activity varied in both time and space, we filtered the location data both spatially and 
temporally. We considered spawning event use along the entire BC and SEAK coast. We created buffers of $22 \mathrm{~km}$ radius around documented spawning locations using the Buffer Wizard in ArcGIS 9.1. We considered a scoter location to be at a spawning event if the scoter was within $22 \mathrm{~km}$ of the centroid of an active spawning management section. The $22 \mathrm{~km}$ radius is based on the 95th percentile of mean interfix distances (the distance between subsequent locations) for VHF radio-fitted surf scoters in late winter when herring spawn was available (Lok et al. 2008). Once we selected the data from scoters that spatially overlapped with the herring spawning event (i.e. within a $22 \mathrm{~km}$ radius buffer), we filtered the data temporally by comparing the date of the scoter location to the mean date of herring spawning within that management section. Locations were only considered as an active spawning event if the date was on, or within $21 \mathrm{~d}$ following, the mean spawning date, which we considered to be the most representative date of spawning within a management section (B. McCarter pers. comm). We chose a period of $21 \mathrm{~d}$ to account for the presence of eggs from 1.5 to $3 \mathrm{wk}$ after deposition and the possibility of spawning events initiated after the mean spawning date within a management section.

The locations of scoters at active spawning events were used to calculate metrics of spawn use by scoters. The metrics included the number of scoters located at spawning events, the number of spawning

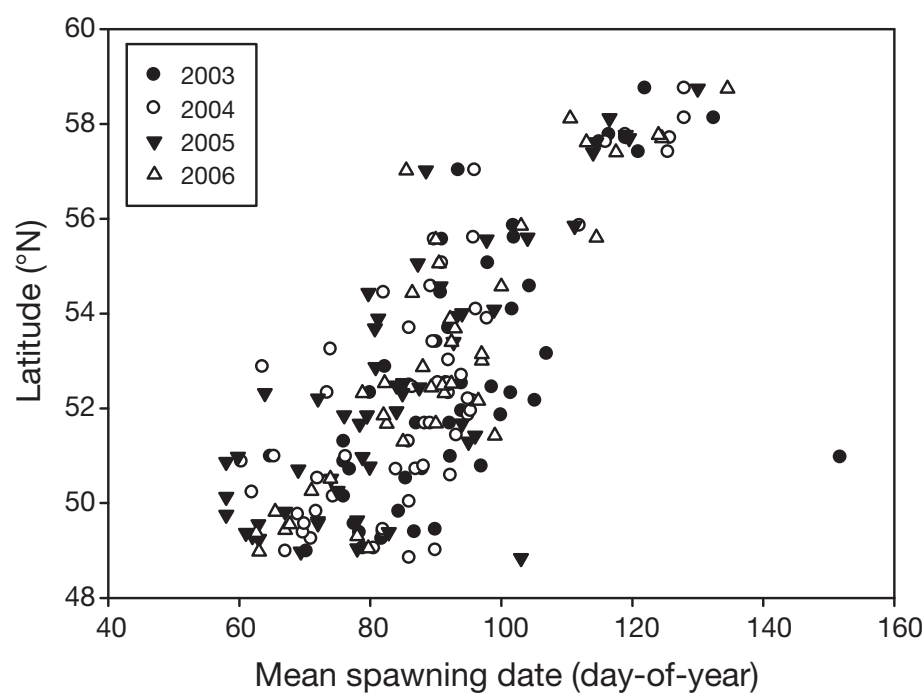

Fig. 2. Clupea pallasi. Latitude and mean spawning date for all management sections with documented Pacific herring spawning activity along the British Columbia and southeast Alaska coasts from 2003 to 2006. Day-of-year is scaled so 1 January $=1$ events visited by an individual scoter, and the proportion of all scoter locations at herring spawning events.

Aerial survey data for SEAK were imported into ArcGIS 9.1 to create a map of surf scoter group locations, scoter abundance, and herring spawning distribution within each survey region (Ketchikan, Juneau, and Haines). We categorized surveys as before spawning and during spawning based on the timing of herring spawning activity within each survey area and the dates of surveys. We calculated several metrics of habitat use before and during spawning. We calculated the density of scoters along the shoreline within the survey areas before and during spawning activity and weighted the locations of the studied scoter flocks by group size to calculate a mean distance from individual scoter locations to herring spawning events. To account for variation in the proportion of coastline with available spawn, we calculated a density of scoters per $\mathrm{km}$ of available spawn. In addition, we used the Buffer Wizard in ArcGIS 9.1 to create a buffer of $1 \mathrm{~km}$ around documented spawning locations to determine the number of scoters, and the proportion of all scoters, observed within $1 \mathrm{~km}$ of herring spawning events.

\section{RESULTS}

\section{Spawning progression and migration patterns}

Variation in the latitude of spawning activity was clearly related to the day of the year and year (Fig. 2). Within the candidate model set, the Day-of-year + (Day-of-year $\times$ Year) model was the most strongly supported model $\left(w_{i}=0.55, \mathrm{R}^{2}=0.61\right)$, and the Dayof-year + Year model received slightly more than half of the support of the most strongly supported model $\left(w_{i}=0.32, \mathrm{R}^{2}=0.61\right)$ (Table 1$)$. Using data from all of the years combined, the regression equation describing herring spawn latitude as a function of the day of the year alone was herring spawn latitude $=41.73$ $( \pm 0.67$ standard error $[\mathrm{SE}])+0.12( \pm 0.01) \times$ Day-ofyear. In addition, this relationship varied somewhat inter-annually, with an inference of differences in both the intercepts and slopes among years supported by the data (Table 2 ).

We compared the latitude of the PTT-fitted surf scoter locations to the predicted latitude of spawning activity for the same day of year for all of the study years combined. The predicted spawning latitude explained some of the variation in the surf scoter latitudes $\left(R^{2}=0.21\right)$. The relationship between the predicted spawning latitude and surf scoter latitude was 
Table 1. Summary of AIC results from general linear models assessing variation in latitude of Pacific herring Clupea pallasi spawning activity along the coasts of British Columbia and southeast Alaska from 2003 to 2006. Number of parameters $(K)$ includes +1 for intercept and +1 for model variance. Candidate models are listed by $\Delta \mathrm{AIC}_{\mathrm{c}}$. Note that $\mathrm{AIC}_{\mathrm{c}}$ weights $\left(w_{\mathrm{i}}\right)$ sum to 1 and indicate the relative support for each candidate model. For day-of-year, 1 January $=1$

\begin{tabular}{|lcrrrcc}
\hline Model & $\begin{array}{c}\text { Parameters } \\
(K)\end{array}$ & $\mathrm{AIC}_{\mathrm{c}}$ & $\Delta \mathrm{AIC}_{\mathrm{c}}$ & $W_{\mathrm{i}}$ & $\mathrm{R}^{2}$ \\
\hline Day-of-year + Day-of-year $\times$ Year & 6 & 228.18 & 0.00 & 0.55 & 0.61 \\
Day-of-year + Year & 6 & 229.26 & 1.08 & 0.32 & 0.61 \\
Day-of-year & 3 & 232.11 & 3.93 & 0.08 & 0.59 \\
Day-of-year + Year + Day-of-year $\times$ Year & 9 & 232.87 & 4.69 & 0.05 & 0.61 \\
Null & 2 & 406.05 & 177.87 & 0.00 & na \\
Year & 5 & 410.31 & 182.12 & 0.00 & 0.01 \\
& & & & & & \\
\hline
\end{tabular}

Table 2. Summed Akaike weights $\left(w_{\mathrm{i}}\right)$, weighted parameter estimates, and unconditional standard errors (SEU) of weighted parameter estimates calculated from all candidate models of the latitude of Pacific herring Clupea pallasi spawning activity along the coasts of British Columbia and southeast Alaska from 2003 to 2006. Day-of-year is scaled so 1 January $=1$. Categorical variable year 2006 is set as the reference value in all candidate models

\begin{tabular}{|lccc|}
\hline Parameter & $\begin{array}{c}\text { Summed } \\
W_{\mathrm{i}}\end{array}$ & $\begin{array}{c}\text { Weighted para- } \\
\text { meter estimate }\end{array}$ & SEU \\
\hline Intercept & 1 & 41.43 & 0.77 \\
Day-of-year & 1 & 0.13 & 0.01 \\
Year & & & \\
2003 & 0.37 & -0.13 & 0.43 \\
2004 & 0.37 & -0.08 & 0.27 \\
2005 & 0.37 & 0.14 & 0.25 \\
Day-of-year $\times 2003$ & 0.60 & -0.01 & 0.00 \\
Day-of-year $\times 2004$ & 0.60 & 0.00 & 0.00 \\
Day-of-year $\times 2005$ & 0.60 & 0.00 & 0.00 \\
\hline
\end{tabular}

positive, as expected, but the slope was $<1.0$ (surf scoter latitude $=19.11( \pm 2.65)+0.64( \pm 0.05) \times$ predicted spawn latitude). This finding indicated that surf scoters showed a delayed progression up the coast in comparison to herring spawning activity.

We also found that the residuals from the relationships between the day of the year and scoter locations were positively correlated with the residuals from a day-of-year and herring-spawning latitude relationship, although there was a high degree of variation in the relationship $\left(R^{2}=0.02\right)$. However, the relationship between the residuals was strongly supported $\left(w_{i}=0.99\right)$ relative to a null model, indicating that spatiotemporal relationships between scoter locations and spawning events existed well beyond the shared general but variable phenology of northward progression.

\section{Spawning event use metrics}

The patterns of PTT-fitted surf scoter spring migration generally paralleled those of northward-progressing herring spawn availability and varied from year to year (Fig. 3). However, the majority of tracked surf scoters were located at spawning events at least once. Of 51 individuals located within BC and SEAK, 31 $(60 \%)$ were located at a spawning event at least once during spring migration. Those 31 individuals were located at spawning events for an average of $33 \pm 4 \%$ of their total locations and visited $2.1 \pm 0.6$ spawning events during coastal spring migration through $\mathrm{BC}$ and SEAK. Including all of the tracked scoters $(n=51), 24 \%$ of all of the sampled scoter locations were detected at spawning events during spring migration.

The use of all 3 survey regions was relatively low prior to the spring migration period and very high during the spawning/migration period, with $>100000$ scoters observed in the Haines region during surveys in May (Table 3). The mean distance to spawning events also varied among the survey areas, with scoters in the Ketchikan and Juneau regions showing marked decreases in distance to spawning events between pre-spawning and spawning surveys, while scoters in the Haines region showed little change in distance to spawning events (Table 3). The use of spawning events varied markedly among the survey areas (Table 3). When the amount of coastline with available spawn was considered relative to scoter densities, the number of scoters per length of coastline with spawning herring was highest in the Haines region, where there was little coastline with spawning herring and high numbers of scoters (Table 4).

\section{DISCUSSION}

We found moderate support for the silver wave hypothesis, suggesting that during spring migration, surf scoters take advantage of the availability of herring spawn as an abundant food resource. Data consistent with the silver wave hypothesis include our finding that herring spawning activity is initiated later in the spring at higher latitudes, creating a northward progression of food availability for scoters. The northward progression of herring spawning 

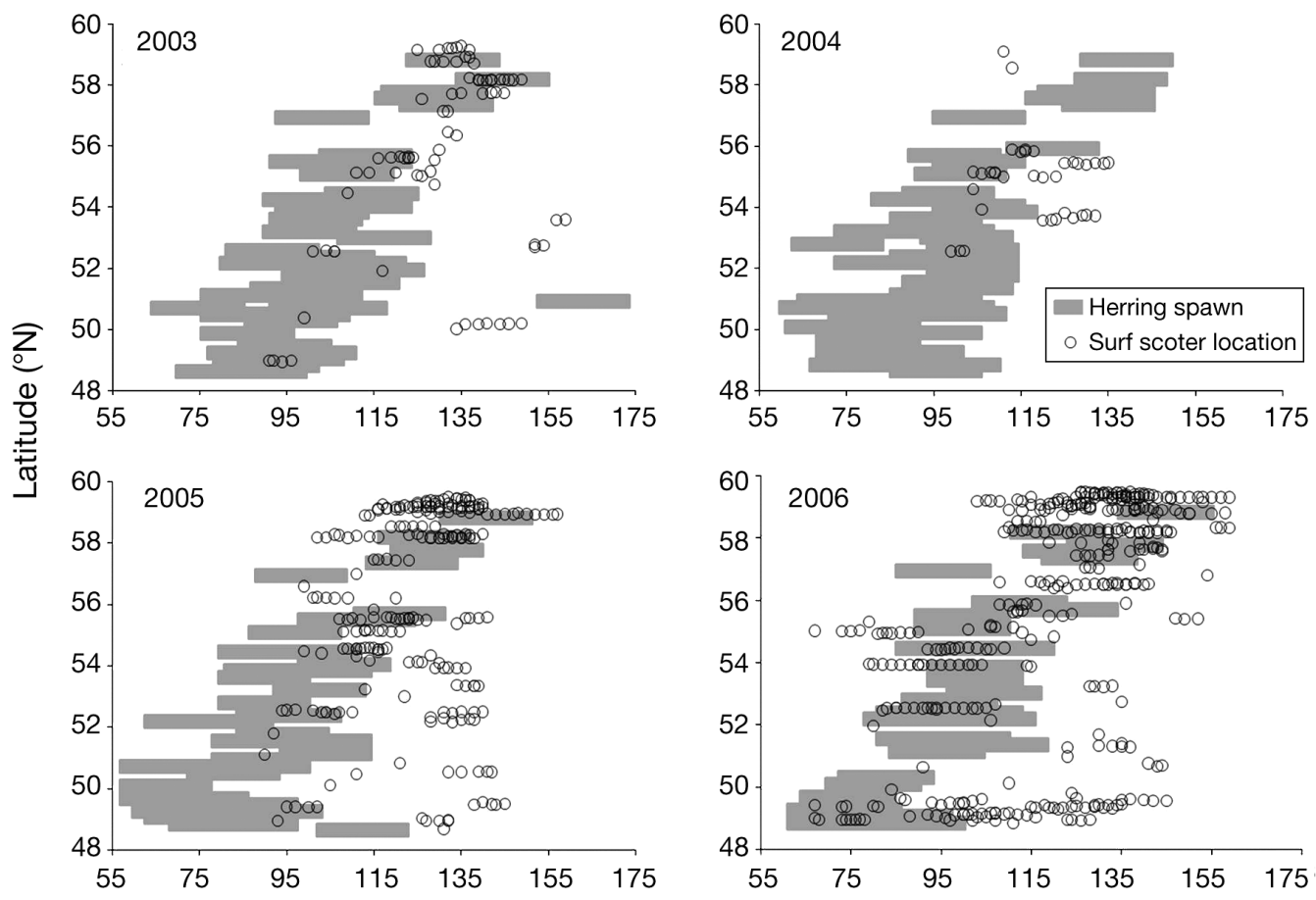

Day-of-year

Fig. 3. Melanitta perspicillata. Comparison of herring spawn availability and locations of PTT-fitted surf scoters along the coasts of British Columbia and southeast Alaska from 2003 to 2006. Herring spawn availability (shaded area) was determined based on spawning times and estimates of the time before eggs hatch (mean spawn date +21 d). Day-of-year is scaled so

$$
1 \text { January }=1
$$

Table 3. Melanitta perspicillata. Summary of spawning event use metrics for surf scoters observed during aerial surveys in 3 regions in southeast Alaska from April to May 2006. Pre-spawning surveys in all regions were conducted from 1 to 2 April 2006. Spawning surveys were conducted on 20 April and 24 April 2006 in Ketchikan, 8 May 2006 in Juneau, and 9 May and 15 May 2006 in Haines. (-) No data available

\begin{tabular}{|c|c|c|c|c|c|}
\hline \multirow{2}{*}{ Metric } & \multirow{2}{*}{ Survey area } & \multicolumn{2}{|c|}{ Pre-spawning surveys } & \multicolumn{2}{|c|}{ Spawning surveys } \\
\hline & & Survey 1 & Survey 2 & Survey 1 & Survey 2 \\
\hline \multirow{3}{*}{ Number of scoters observed } & Ketchikan & 729 & - & 77860 & 24530 \\
\hline & Juneau & 2442 & - & 51160 & - \\
\hline & Haines & 452 & 120690 & - & 141600 \\
\hline \multirow[t]{3}{*}{ Scoters within $1 \mathrm{~km}$ of spawning (\%) } & Ketchikan & 28 & - & 98 & 90 \\
\hline & Juneau & 3 & - & 49 & - \\
\hline & Haines & 0 & 3 & - & 15 \\
\hline \multirow[t]{3}{*}{ Mean distance to spawning event $(\mathrm{km})$} & Ketchikan & 7.3 & - & 0.4 & 0.9 \\
\hline & Juneau & 21.9 & - & 9.5 & - \\
\hline & Haines & 52.9 & 42.0 & - & 55.5 \\
\hline
\end{tabular}

activity was strongly related to the day of the year, indicating that spawn availability is a reasonably predictable seasonal resource during migration on a broad scale. A study of the variation in the temporal and spatial availability of herring spawn along the BC coastline showed that the reliability and timing of herring spawning events are quite variable from year to year at small geographic scales, but the events become increasingly predictable at broader geographic scales (Willson \& Womble 2006). Because herring eggs are available to predators for up to $3 \mathrm{wk}$ after the initiation of spawning (Haegele \& Schweigert 1985, Hay 1985), the eggs are available at multiple locations, creating generally continuous availability of spawn along the coast during spring. This means that variation in herring spawning timing 
Table 4. Melanitta perspicillata. Percentage of surveyed shorline with spawing activity and densities (scoters $\mathrm{km}^{-1}$ ) of surf scoters observed along shoreline survey routes in 3 regions in southeast Alaska from April to May 2006. Prespawn surveys in all regions were conducted from 1 to 2 April 2006. Spawning surveys were conducted on 20 April and 24 April 2006 in Ketchikan, 8 May 2006 in Juneau, and 9 May and 15 May 2006 in Haines

\begin{tabular}{|lccc|}
\hline & Ketchikan & Juneau & Haines \\
\hline $\begin{array}{l}\text { \% of surveyed shoreline } \\
\text { with spawning activity }\end{array}$ & 7.3 & 5.8 & 1.8 \\
$\begin{array}{l}\text { Scoter density } \\
\text { Pre-spawning survey }\end{array}$ & 1.3 & 5.3 & 1.1 \\
$\begin{array}{l}\text { Spawning survey } \\
\text { Spawning survey density } \\
\text { at spawning events }\end{array}$ & 144.1 & 306.0 & 359.0 \\
\hline
\end{tabular}

and distribution may not constrain habitat use by highly mobile predators, such as scoters (Willson \& Womble 2006). Pre-migratory surf scoters show increased movements in response to herring spawn at a local scale (Lok et al. 2008) and are presumably capable of moving in search of spawn at larger scales, particularly during migration.

We found that surf scoter migration generally coincided with the northward progression of herring spawn within the study years but did not follow the same pattern closely. The temporal and spatial patterns of herring spawn availability explained only part of the variation in surf scoter spring migration locations. Not all individuals used spawning events, and not all of the locations of each individual were at spawning events. Our metrics of the association between scoters and spawn may be minimum estimates because not all spawning events along the entire coast can be documented with complete certainty, and there are often smaller subsequent spawning events after the mean spawning date for a management section that may go undetected (Haegele \& Schweigert 1985). However, there was considerable use of spawning events during migration; $60 \%$ of the tracked surf scoters used herring spawning events at some point during migration, despite the very small proportion of coastline used by spawning herring. In particular, the aerial survey data showed that when spawn was available, it was used heavily, as evidenced by the high densities of scoters at the small number of available herring spawn sites in the Haines region. This finding lends support to the silver wave hypothesis but suggests that herring spawn availability is not the only important factor driving scoter migration strategies and habitat use.

The spatial and temporal availability of resources influences stopover site use and migration timing (Ottich \& Dierschke 2003, van der Graaf et al. 2006). For highly mobile scoters, the generally continuous availability of herring spawn and abundant alternative foraging habitat likely gives them flexibility to modify their migration timing and habitat use. Surf scoters might use a combination of stopover sites that provide varying habitat resources (Lok et al. 2011). The location data suggest that although some surf scoters do appear to generally follow a silver wave of herring spawn availability, they are likely making use of alternative food sources at sites during migration as well. It is likely that herring spawn is an important resource at a site while it is present, but other resources are used once the eggs are no longer available. Habitat use by surf scoters during winter is related to shoreline characteristics and associated bivalve prey distribution and densities (Žydelis et al. 2006). Recent habitat mapping in SEAK indicates that the distribution of blue mussels is more continuous along shorelines closer to the mainland coast (ShoreZone Program 2006), which could provide predictable food resources for scoters (Lok et al. 2011).

Very high numbers of surf scoters were observed in Lynn Canal (Fig. 1), despite the lack of herring spawn in the area during the study years. Lynn Canal is the most northeastern marine waterbody in SEAK, creating a natural break and stopover area for migrating birds. This area provides scoters with the last access to marine resources along their coastal migration route before they turn inland to breed (Lok et al. 2011). Not all spring migration habitats serve the same resource function (Mehlman et al. 2005), and Lynn Canal may be distinct as a final migration staging area before inland migration. However, it is also important to note that herring numbers in Lynn Canal have declined markedly in the last 4 decades, and herring spawn availability in this area has been reduced to a small fraction of the former distribution (Willson \& Womble 2006), when it occurs at all. It is possible that this region is heavily used because it was traditionally used as a staging site when herring stocks were more robust.

Marine birds are generally recognized to be responsive to spatial and temporal variation in prey availability (Weimerskirch et al. 1994, Ainley et al. 1996, Guillemette \& Himmelman 1996, Hunt et al. 1998, Litzow et al. 2002, Žydelis et al. 2006) and to adjust their foraging efforts and locations in response to ephemeral or novel prey (Marston et al. 2002, 
Christie \& Reimchen 2005, Lacroix et al. 2005, Lewis et al. 2007b, Lok et al. 2008, Anderson et al. 2009). However, to our knowledge, the present study is the first documentation of spatiotemporal relationships between migrating marine birds and the ephemeral and spatially fluctuating food resource represented by spawning marine fish. We suspect that this phenomenon may occur in other bird taxa, particularly because many types of marine birds are known to aggregate at spawning events to forage either on congregated adult fish or the spawn (Haegele 1993, Vermeer et al. 1997, Bishop \& Green 2001, Sullivan et al. 2002). Herring eggs are an easily accessible, highenergy, lipid-rich food item (Paul \& Paul 1999) and have been shown to be used to build energy reserves prior to and during spring migration and reproduction (Bishop \& Green 2001, Bond \& Esler 2006, Willson \& Womble 2006, Anderson et al. 2009). Vermeer et al. (1997) speculated that the fraction of a population using herring spawning events could indicate the dependence of that population on herring spawn for acquiring energy. Species that deplete winter foods, such as surf scoters (Kirk et al. 2007, Lewis et al. 2007a), might rely heavily on herring spawn for acquiring energy reserves in late winter and early spring (Bond \& Esler 2006), and species that aggregate at herring spawning events may depend on this resource for breeding in less resource-rich areas (Žydelis \& Esler 2005). Anderson et al. (2009) found that in late winter and spring, surf scoters reached their greatest body mass during late April to midMay while migrating through SEAK. Although plasma triglyceride data from this period suggested that mass gain was not entirely related to spawn consumption, surf scoters aggregated to consume spawn whenever it was available.

The availability and quality of resources during spring migration may have implications for success during subsequent stages of the annual cycle (Ankney \& MacInnes 1978, Alisauskas \& Ankney 1992, Warnock \& Bishop 1998, Smith \& Moore 2003, Morrison \& Hobson 2004). Several researchers have described cross-seasonal effects of spring habitats on reproductive performance by migratory waterfowl (Anteau \& Afton 2004, Reed et al. 2004, Schmutz et al. 2006), and because these events provide the energy and nutrients required for reproduction, it follows that population dynamics might be influenced by habitat conditions during spring migration. Although it is not clear whether herring spawn directly influences population dynamics, spawning events are clearly preferred foraging sites for surf scoters (Anderson et al. 2009).
Variation in non-breeding habitat, such as areas supporting herring spawn, may have important conservation implications. Herring spawning events are heavily used by many marine bird and mammal species (Haegele 1993, Sullivan et al. 2002, Willson \& Womble 2006). However, traditional spawning events in many areas have declined in numbers and shifted in distribution, and species are increasingly restricted to fewer spawning sites (Stick 2005, Willson \& Womble 2006). Understanding the cross-seasonal links between the use of herring spawn during late winter and the energy requirements for migration and reproduction is critical for the management and conservation of scoter populations and many other marine species that use herring spawn.

Acknowledgements. This work was conducted following guidance from animal care and use committees and with permits from the California Department of Fish and Game, Canadian Wildlife Service, U.S. Fish and Wildlife Service, USGS Bird Banding Laboratory, USGS Western Ecological Research Center, Simon Fraser University, Washington Department of Fish and Wildlife, and Secretaría de Medio Ambiente y Recursos Naturales (SEMARNAT) (through Ducks Unlimited de Mexico and Permit 7232). Funding was provided by the Sea Duck Joint Venture, Environment Canada/Canadian Wildlife Service Pacific and Yukon Region, Environment Canada's Georgia Basin Action Plan, USGS/Alaska Science Center, and USGS Western Ecological Research Center Coastal Ecosystems Program with support from the Calfed Ecosystem Restoration Program. E.K.L. was supported by the Sea Duck Joint Venture, Environment Canada Science Horizons Program and the Centre for Wildlife Ecology at Simon Fraser University. We thank the Department of Fisheries and Oceans, the Alaska Department of Fish and Game, and J. Womble for the herring spawn data. We thank pilots L. Bennett and D. Doyon. The use of trade, product, or firm names in this publication is for descriptive purposes only and does not imply endorsement.

\section{LITERATURE CITED}

Ainley DG, Spear LB, Allen SG (1996) Variation in the diet of Cassin's auklet reveals spatial, seasonal, and decadal occurrence patterns of euphausiids off California, USA. Mar Ecol Prog Ser 137:1-10

Alisauskas RT, Ankney CD (1992) The cost of egg laying and its relationship to nutrient reserves in waterfowl. In: Batt BDJ, Afton AD, Anderson MG, Ankney CD, Johnson DH, Kadlec JA, Krapu GL (eds) Ecology and management of breeding waterfowl. University of Minnesota Press, Minneapolis, MN, p 30-61

Anderson EM, Lovvorn JM, Wilson MT (2008) Reevaluating marine diets of surf and white-winged scoters: interspecific differences and the importance of soft-bodied prey. Condor 110:285-295

Anderson EM, Lovvorn JM, Esler D, Boyd WS, Stick KC (2009) Using predator distributions, diet, and condition to evaluate seasonal foraging sites: sea ducks and herring spawn. Mar Ecol Prog Ser 386: 287-302 
Ankney CD, MacInnes CD (1978) Nutrient reserves and reproductive performance of female lesser snow geese. Auk 95:459-471

> Anteau MJ, Afton AD (2004) Nutrient reserves of lesser scaup (Aythya affinis) during spring migration in the Mississippi Flyway: a test of the spring condition hypothesis. Auk 121:917-929

- Bishop MA, Green SP (2001) Predation on Pacific herring (Clupea pallasi) spawn by birds in Prince William Sound, Alaska. Fish Oceanogr 10:149-158

Bond JC, Esler D (2006) Nutrient acquisition by female harlequin ducks prior to spring migration and reproduction: evidence for body mass optimization. Can J Zool 84: 1223-1229

Burnham KP, Anderson DR (2002) Model selection and inference: a practical information-theoretic approach, 2nd edn. Springer-Verlag, New York, NY

Christie KS, Reimchen TE (2005) Post-reproductive salmon, Oncorhynchus spp., as a major nutrient source for large aggregations of gulls, Larus spp. Can Field Nat 119: 202-207

> De La Cruz SW, Takekawa JY, Wilson MT, Nysewander DR and others (2009) Spring migration routes and chronology of surf scoters (Melanitta perspicillata): a synthesis of Pacific coast studies. Can J Zool 87:1069-1086

DFO (Department of Fisheries and Oceans) (2008) Pacific herring geographical bulletin. Available at www.pac.dfompo.gc.ca/science/species-especes/pelagic-pelagique/ herring-hareng/herspawn/pages/default5-eng.htm. Accessed 15 May 2007

Douglas DC (2006) PCS-SAS Argos Filter v7.03 software documentation. US Geological Survey Alaska Biological Science Center, Anchorage, AK. Available at http:// alaska.usgs.gov/science/biology/spatial/douglas.html. Accessed 11 July 2008

Drent RH, Ebbinge BS, Weijand B (1978) Balancing the energy budgets of Arctic-breeding geese throughout the annual cycle: a progress report. Verhandl Ornithol Gesells Bayern 23:239-264

Environmental Systems Research Institute (2005) ArcGIS, Version 9.1. Redlands, CA

Guillemette M, Himmelman JH (1996) Distribution of wintering common eiders over mussel beds: Does the ideal free distribution apply? Oikos 76:435-442

Haegele CW (1993) Seabird predation of Pacific herring, Clupea pallasi, spawn in British Columbia. Can Field Nat 107:73-82

> Haegele CW, Schweigert JF (1985) Distribution and characteristics of herring spawning grounds and description of spawning behaviour. Can J Fish Aquat Sci 42:s39-s55

> Hay DE (1985) Reproductive biology of Pacific herring (Clupea harengus). Can J Fish Aquat Sci 42:s111-s126

Hay DE, McCarter PB (2007) Herring spawning areas of British Columbia: a review, geographical analysis and classification. Can Manuscr Rep Fish Aquat Sci 2019. Available at www.pac.dfo-mpo.gc.ca/science/speciesespeces/pelagic-pelagique/herring-hareng/herspawn/ pages/project-eng.htm. Accessed 15 May 2007

> Hunt GL, Russell RW, Coyle KO, Weingartner T (1998) Comparative foraging ecology of planktivorous auklets in relation to ocean physics and prey availability. Mar Ecol Prog Ser 167:241-259

Iverson SA, Boyd WS, Esler D, Mulcahy DM, Bowman TD (2006) Comparison of the effects and performance of four types of radiotransmitters for use with scoters. Wildl Soc
Bull 34:656-663

Kaiser GW, Derocher AE, Crawford S, Gill MJ, Manley IA (1995) A capture technique for marbled murrelets in coastal inlets. J Field Ornithol 66:321-333

Kirk M, Esler D, Boyd WS (2007) Morphology and density of mussels on natural and aquaculture structure habitats: implications for sea duck predators. Mar Ecol Prog Ser 346:179-187

Kirk M, Esler D, Iverson SA, Boyd WS (2008) Movements of wintering surf scoters: predator responses to different prey landscapes. Oecologia 155:859-867

Lacroix DL, Boyd S, Esler D, Kirk M, Lewis TL, Lipovski S (2005) Surf scoters aggregate and forage on ephemerally abundant polychaetes. Mar Ornithol 33:61-65

- Lewis TL, Esler D, Boyd WS, Žydelis R (2005) Nocturnal foraging behavior of wintering surf scoters and whitewinged scoters. Condor 107:637-647

Lewis TL, Esler D, Boyd WS (2007a) Effects of predation by sea ducks on clam abundance in soft-bottom intertidal habitats. Mar Ecol Prog Ser 329:131-144

Lewis TL, Esler D, Boyd WS (2007b) Foraging behaviors of surf scoters and white-winged scoters during spawning of Pacific herring. Condor 109:216-222

Litzow MA, Piatt JF, Prichard AK, Roby DD (2002) Response of pigeon guillemots to variable abundance of high-lipid and low-lipid prey. Oecologia 132:286-295

Lok EK, Kirk M, Esler D, Boyd WS (2008) Movements of premigratory surf and white-winged scoters in response to herring spawn. Waterbirds 31:385-393

> Lok EK, Esler D, Takekawa JY, De La Cruz SEW and others (2011) Stopover habitats of spring migrating surf scoters in Southeast Alaska. J Wildl Manag 75:92-100

> Marston BH, Willson MF, Gende SM (2002) Predator aggregations during eulachon Thaleichthys pacificus spawning runs. Mar Ecol Prog Ser 231:229-236

Mehlman DW, Mabey SE, Ewert DN, Duncan C and others (2005) Conserving stopover sites for forest-dwelling migratory landbirds. Auk 122:1281-1290

Miller MR, Takekawa JY, Fleskes JP, Orthmeyer DL, Casazza ML, Perry WM (2005) Spring migration of northern pintails from California's Central Valley wintering area tracked with satellite telemetry: routes, timing, and destinations. Can J Zool 83:1314-1332

Morrison RIG, Hobson KA (2004) Use of body stores in shorebirds after arrival on high-Arctic breeding grounds. Auk 121:333-344

- Mulcahy DM, Esler D (1999) Surgical and immediate postrelease mortality of harlequin ducks (Histrionicus histrionicus) implanted with abdominal radio transmitters with percutaneous antennae. J Zoo Wildl Med 30: 397-401

Ottich I, Dierschke V (2003) Exploitation of resources modulates stopover behaviour of passerine migrants. J Ornithol 144:307-316

Owen M (1980) Wild geese of the world. Batsford, London

Paul AJ, Paul JM (1999) Energy contents of whole body, ovaries, and ova from pre-spawning Pacific herring. Alaska Fish Res Bull 6:29-34

Reed ET, Gauthier G, Giroux JF (2004) Effects of spring conditions on breeding propensity of greater snow goose females. Anim Biodivers Conserv 27:35-46

Rodway MS, Regehr HM, Ashley J, Clarkson PV and others (2003) Aggregative response of harlequin ducks to herring spawning in the Strait of Georgia, British Columbia. Can J Zool 81:504-514 
Ryder JP (1970) A possible factor in the evolution of clutch size in Ross' goose. Wilson Bull 82:5-13

SAS Institute (2003) SAS, Version 9.1. SAS Institute, Cary, $\mathrm{NC}$

Savard JPL, Bordage D, Reed A (1998) Surf scoter (Melanitta perspicillata). In: Poole A, Gill F (eds) The Birds of North America no. 363. The Birds of North America, Philadelphia, PA, p 1-27

Schmutz JA, Hobson KA, Morse JA (2006) An isotopic assessment of protein from diet and endogenous stores: effects on egg production and incubation behaviour of geese. Ardea 94:385-397

ShoreZone Program (2006) ShoreZone coastal habitat mapping data summary report, Southeast Alaska 20042005. www.coastalandoceans.com. Accessed 25 January 2007

Smith RJ, Moore FR (2003) Arrival fat and reproductive performance in a long-distance passerine migrant. Oecologia 134:325-331

Stick KC (2005) Washington State herring stock status report. Washington Department of Fish and Wildlife, Fish Management Program, Olympia, WA

Sullivan TM, Butler RW, Boyd WS (2002) Seasonal distribution of waterbirds in relation to spawning Pacific herring, Clupea pallasi, in the Strait of Georgia, British Columbia. Can Field Nat 116:366-370

Takekawa JY, De La Cruz SW, Wilson MT, Palm EC and others 2011. Breeding distribution and ecology of Pacific coast surf scoters. In: Wells JV (ed) Boreal birds of North America. Studies in Avian Biology 41. University of Cali-

Editorial responsibility: Rory Wilson,

Swansea, UK fornia Press, Berkeley, CA, p 41-64

van der Graaf AJ, Stahl J, Klimkowska A, Bakker JA, Drent RH (2006) Surfing on a green wave-how plant growth drives spring migration in the barnacle goose (Branta leucopsis). Ardea 94:567-577

Vermeer K (1981) Food and populations of surf scoters in British Columbia. Wildfowl 32:107-116

Vermeer K, Bentley M, Morgan KH, Smith GEJ (1997) Association of feeding flocks of Brant and sea ducks with herring spawn at Skidegate Inlet. Occas Pap Can Wildl Serv 93:102-107

> Warnock N, Bishop MA (1998) Spring stopover ecology of migrant western sandpipers. Condor 100:456-467

Weimerskirch H, Doncaster CP, Cuenotchaillet F (1994) Pelagic seabirds and the marine-environment: foraging patterns of wandering albatrosses in relation to prey availability and distribution. Proc Biol Sci 255:91-97

Willson MF, Womble JN (2006) Vertebrate exploitation of pulsed marine prey: a review and the example of spawning herring. Rev Fish Biol Fish 16:183-200

Womble JN, Willson MF, Sigler MF, Kelly BP, VanBlaricom GR (2005) Distribution of Steller sea lions Eumetopias jubatus in relation to spring-spawning fish in SE Alaska. Mar Ecol Prog Ser 294:271-282

Žydelis R, Esler D (2005) Response of wintering Steller's eiders to herring spawn. Waterbirds 28:344-350

Žydelis R, Esler D, Boyd WS, LaCroix DL, Kirk M (2006) Habitat use by wintering surf and white-winged scoters: Effects of environmental attributes and shellfish aquaculture. J Wildl Manag 70:1754-1762

Submitted: July 20, 2011; Accepted: February 27, 2012 Proofs received from author(s): May 25, 2012 